Bartosz Trębacz, Konflikt braterski w Księdze Rodzaju,

[w:] Cztowiek w relacji do... Rozważania o cztowieku jako istocie relacyjnej,

red. Grzegorz Wąchol, Kraków 2020, s. 249-269.

DOI: http://dx.doi.org./10.15633/9788374388740.15

MGR BARTOSZ TRĘBACZ

\title{
Konflikt braterski w Księdze Rodzaju
}

Artykuł prezentuje zagadnienie konfliktu braterskiego w Księdze Rodzaju. Autor stara się przybliżyć stosunki rodzinne między poszczególnymi postaciami biblijnymi: Kainem i Ablem, Ezawem i Jakubem oraz Józefem i jego braćmi. Istotnym celem badawczym jest wyszukanie możliwych przyczyn danego konfliktu oraz zanalizowanie, czy dany kryzys został zażegnany i czy między braćmi zapanowała harmonia. Ważnym elementem pracy jest sprawdzenie, czy osoby trzecie miały wpływ na eskalację danego konfliktu lub jego zatrzymanie.

\section{Kain i Abel}

Opowiadanie o Kainie i Ablu jest pierwszym opisem relacji braterskiej w Piśmie Świętym. Niestety jest to także pierwszy przypadek morderstwa, i jakby sam ciężar tej zbrodni nie był wystarczający, mamy tu do czynienia z bratobójstwem. Występek Kaina - a raczej jego grzech - zdaje się głównym wątkiem w perykopie Rdz 4, 1-20 pomimo występowania tam również niezwykłej głębi teologicznej 
przy składaniu ofiar ( $\mathrm{Rdz} 4,20)$ czy przy rozmowie Jahwe z Kainem $(\operatorname{Rdz} 4,2)$. Patrząc na występek Kaina, należy zadać parę pytań. Co sprawiło, że pozbawił życia młodszego brata? Jakie były stosunki między nimi? Czy można na podstawie perykopy zarysować głębię ich braterskiej relacji?

W uzyskaniu odpowiedzi mogą okazać się pomocne dwa pierwsze wersety Rdz 4: „Mężczyzna zbliżył się do swojej żony Ewy. A ona poczęła i urodziła Kaina, i rzekła: «Otrzymałam mężczyznę od Pana» (w. 1); „A potem urodziła jeszcze Abla, jego brata. Abel był pasterzem trzód, a Kain uprawiał pole" (w. 2). W pierwszym wersecie można zauważyć nie tylko radość Ewy z narodzenia pierwszego potomka, ale i także pewną dumę. Podkreśla bowiem, że zrodziła mężczyznę. Ewa wie, że zawdzięcza zarówno dar rodzenia, jak i samo dziecko Panu Bogu (por. Rdz 4, 1). Co ciekawe, wiąże się to $z$ jedną z interpretacji znaczenia imienia Kain w języku hebrajskim. Słowo qaniti można tłumaczyć jako „nabyć, otrzymać”,

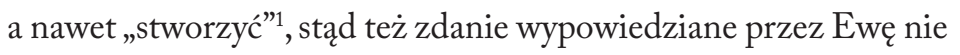
powinno dziwić. Oprócz radości można zauważyć uczucie dumy oraz - pamiętając wydarzenia z raju - nutę nadziei. Być może, mając na uwadze grzech pierwszego mężczyzny, niewiasta wyraża nadzieję, że kolejny mężczyzna, jej syn, nie popełni tego samego błędu co jego ojciec i będzie żył w przyjaźni z Bogiem.

Interesujące, a także pomocne w ustaleniu stosunków między braćmi jest również znaczenie imienia Abel. Po hebrajsku znaczy ono hebel, czyli „marność, nicość, pył”2. Jest to znamienne z dwóch powodów. Po pierwsze Ewa nie komentuje faktu zrodzenia drugiego syna, zostaje on odstawiony na bok. Po drugie Abel ani razu nie podejmuje dialogu z żadną z postaci. Wiemy jedynie, że brat

1 Por. M. Peter, Prehistoria biblijna, Poznań 1994, s. 67 (Biblioteka Pomocy Naukowych - Papieski Wydział Teologiczny w Poznaniu, 10).

2 Por. M. Peter, Prehistoria biblijna, dz. cyt., s. 67-68. 
polecił mu, aby poszedł z nim na pole (w. 8). Po trzecie zostanie pozbawiony życia przez własnego brata.

W perykopie $\mathrm{Rdz} 4$, 1-17 - oprócz informacji, jakie prace wykonywali - nie znajdziemy opisu wprost, jakie stosunki mieli dwaj bracia. Kain był rolnikiem, podobnie jak jego ojciec (w. 2). Była to praca wymagająca dużej siły. Z kolei Abel był pasterzem. W Piśmie Świętym to młodsi synowie zajmowali się pasterstwem czy opieką nad trzodą (por. Rdz 37, 23; $1 \mathrm{Sm} \mathrm{17,15).} \mathrm{Nie} \mathrm{wiemy,} \mathrm{jaka}$ była różnica wieku między nimi. Niektórzy egzegeci na podstawie wersetu pierwszego i drugiego $\mathrm{Rdz} 4$ widzieli w nich bliźnięta ${ }^{3}$. Można jedynie założyć, że były to niczym niewyróżniające się stosunki między braćmi, ponieważ gdyby istniała między nimi większa wrogość czy nienawiść, fakt ten zostałby odnotowany przez autora.

Trzeba pamiętać o tym, że opowiadanie o Kainie i Ablu miało tłumaczyć dwa tematy. Pierwszy to wyjaśnienie etiologiczne istnienia wrogości między plemionami Kainitów oraz Setytów, za których protoplastów uważano Kaina i Seta. Kainitom przypisywano wiele negatywnych cech, którymi charakteryzował się przeklęty przez Boga Kain. Do takich należała bezbożność, krwiożerczość czy życie banity, dlatego w historii egzegezy nie brakowało interpretacji, jakoby wydarzenia zawarte w $\mathrm{Rdz} 4$ miały stanowić nie tylko alegorię walki między dwoma plemionami, ale także etiologię i wyjaśnienie przyczyn tej wrogości ${ }^{4}$. Drugi temat to rozwój grzechu przez zbrodnie protoplasty Kainitów. Rdz 4 jest pokłosiem wydarzeń z Rdz 3, to znaczy pojawienia się zła na świecie przez działanie rodziców Kaina i Abla. Poprzez ohydną zbrodnię Kaina grzech niewoli kolejnego człowieka przechodzi na innych.

3 Por. Księga Rodzaju. Wstep, przektad zoryginatu, komentarz, oprac. S. Łach, Poznań 1962, s. 224 (Pismo Święte Starego Testamentu, 1.1).

4 Por. Księga Rodzaju. Wstęp, przektad z oryginatu, komentarz, dz. cyt., s. 234. 
I będzie przechodził dalej bez zdecydowanego działania Boga do czasu potopu.

Dopiero w wersetach o składaniu ofiar z pierwocin można zauważyć stosunek Kaina do swojego brata: „[... [ Pan wejrzał na Abla i jego ofiarę; na Kaina zaś i jego ofiarę nie chciał patrzeć. Smuciło to Kaina bardzo i chodził z ponurą twarzą” (Rdz 4, 4-5). Interesujące jest, jakie wrażenie mógł odnieść Kain. Czy Bóg nie zauważył tego, co Mu ofiarował, czy nie chciał na niego patrzeć? Czy zarówno ofiara Abla, jak i on sam tak się Bogu spodobali, że cała uwaga Jahwe skupiła się na nich? Rolnik był na tyle rozgoryczony całą sytuacją, że smutek odbijał się na jego twarzy (w. 5). Z punktu widzenia Kaina spotkała go krzywda. Według niego Bóg nie tylko przedłożył ofiarę młodszego brata nad jego, ale także odrzucił go. Mógł się przez to czuć wzgardzony, a nawet upokorzony. Autor zaznacza, że Kain mial ponurą twarz (w. 5). W innych przekładach Pisma twarz Kaina była pochylona w dół. Wiktor Pikor podkreśla, że pochylona twarz oznacza wielki smutek, jaki odczuwa starszy brat, oraz zerwanie relacji $\mathrm{z}$ innymi ${ }^{5}$. I to właśnie $\mathrm{w}$ tej postawie należy upatrywać źródła zmartwień Kaina. Bóg zauważa cierpienie odmalowujące się na twarzy Kaina i pyta go o jego przyczynę (w. 6). Stwierdza: „Przecież gdybyś postępował dobrze, miałbyś twarz pogodną” (w. 7). Kain, zamiast szukać winy w bracie czy w Panu Bogu, powinien szukać grzechu w sobie. Jest nim nie tylko zazdrość o młodszego brata, ale i - co najważniejsze - zła relacja z Panem Bogiem. Stwórca widzi to wszystko i wchodzi w bliską relację z Kainem. Stara się przemówić do jego rozsądku i sumienia. Ponura twarz rolnika zwiastuje bowiem także niebezpieczeństwo grożące Ablowi.

Bóg przyjmuje nie tylko rolę ojca, ale i pedagoga. Niezwrócenie uwagi na Kaina i jego pierwociny niekoniecznie miało na celu

5 Por. W. Pikor, Zbawienie - zmaganie o Boże oblicze na twarzy Kaina (Rdz 4, 1-16), „Verbum Vitae” 1 (2002), s. 33. 
zignorowanie go. Pan Bóg chciał zasygnalizować raczej problem Kaina i zmusić go do refleksji i nawrócenia ${ }^{6}$. Mówi dokładnie, co powinien zrobić mężczyzna, by przywrócić harmonię swojemu sumieniu: „Jeśli zaś nie będziesz dobrze postępował, grzech leży u wrót na ciebie i czyha na ciebie, a przecież to ty masz nad nim panować” ( $\operatorname{Rdz} 4$, 7). Bóg daje Kainowi szansę, by ocalić dwie osoby - ofiary jego grzechu. Kain może wybrać i uniknąć błędu swoich rodziców, czyli zatryumfować nad złem i być w bliskiej relacji z Panem Bogiem. Niestety robi najgorszą możliwą rzecz, gdy rozmawia z Bogiem - milczy. Znamienne jest to, że wcześniej w Księdze Rodzaju tylko wąż milczał podczas wyroku w raju (por. Rdz 3, 13). Mamy tu do czynienia z symbolicznym zerwaniem relacji i więzi z Panem Bogiem, a także z niewypowiedzianą negacją Jego miłości. Podczas swojego milczenia Kain przegrał walkę $\mathrm{z}$ grzechem.

Z wersetów 6-7 zarysowuje się niezwykle głęboka nauka o relacjach międzyosobowych. Abel żyjący w przyjaźni z Bogiem i przez to posiadający dobre relacje z Nim cieszy się łaską Bożą. Kain jest nieszczęśliwy z powodu braku wewnętrznej harmonii i niewłaściwej relacji z Panem Bogiem i przez to odczuwa smutek i złość względem swojego brata. Gdyby miał głęboką więź z Jahwe, to miałby podobne relacje $z$ Ablem. Wreszcie rolnik mógł być mądrzejszy od swoich rodziców i nie popełnić tego samego błędu co oni, czyli błędu nieopowiedzenia się po stronie Pana Boga. Niestety decyduje się na inny krok. Jego złość jest tak wielka, że dokonuje straszliwej zbrodni.

Kain rozmawia $z$ Ablem i poleca mu, aby poszedł za nim na pole. W przekładzie hebrajskim występuje wajjomer, czyli „podnosić głos”

6 Por. Ksiega Rodzaju, cz. 1, Rozdziaty 1-11, wstęp, tłum. z oryginału, komentarz oprac. J. Lemański, Częstochowa 2013, s. 282 (Nowy Komentarz Biblijny. Stary Testament, 1.1). 
czy „kłócić się” $(\operatorname{Rdz} 4,8)^{7}$. Nie był to istotny powód kłótni, mogła to być sprzeczka na temat obowiązków, jakie bracia wykonywali. Być może dlatego pomimo agresywności i ponownie ponurego wyrazu na twarzy Kaina Abel ufa bratu i idzie za nim, nie przeczuwając podstępu. Nawet jeśli Kain zaplanował zbrodnię, to Abel dalej traktował go jak starszego brata. Nienawiść jednak kompletnie zdominowała Kaina i pozbawił on życia swojego młodszego brata (w. 8). Chęć wyprowadzenia Abla daleko od domu miała służyć nie tylko próbie dokonania morderstwa poza zasięgiem oczu innych, ale i także - jak się wydawało Kainowi - poza zasięgiem oczu samego Boga.

Kain nie tylko pozbawia życia swojego młodszego brata, ale i przelewa jego krew na ziemi, za którą był odpowiedzialny (w. 8). I to właśnie owa przesiąknięta krwią Abla ziemia wskaże go jako winnego zbrodni (w. 10). Przelana krew jest także występkiem przeciwko Bogu, jako że jest On dawcą życia, a krew była uważana za siedlisko życia ${ }^{8}$. Podczas przesłuchania Kain udaje, że nie wie, co się stało z jego bratem. Tak samo jak jego ojciec Adam nie przyznaje się do czynu. Zostaje przez to przeklęty przez Pana Boga. I tak samo jak Adam musi się udać na wygnanie, przez co przenosi zło dalej.

\section{Ezaw i Jakub}

Ezaw i Jakub byli synami Izaaka i Rebeki. Ich los został przypieczętowany lub precyzyjniej zapowiedziany, gdy synowie przebywali

7 Por. M. Majewski, Biblijna bistoria zbawienia, wyd. 2 popr., Kraków 2017, s. 54, https://www.academia.edu/10942402/BIBLIJNA_HISTORIA_ZBAWIENIA (20.08.2019).

8 Por. C. Schedl, Starożytny Wschód i prehistoria biblijna, tlum. S. Stańczyk, Tuchów 1995, s. 290 (Historia Starego Testamentu, 1). 
jeszcze w łonie Rebeki ( $R d z$ 25, 21). Wierszem zostają przepowiedziane losy bliźniaków oraz to, który z braci zdominuje drugiego. Nawet ukryte znaczenia ich imion potrafią wiele zdradzić o ich walce już w łonie matki. Ezaw zostaje nazwany czerwonym (hebr. $A d-$ mai) nie tylko z racji owłosienia, ale i z powodów etiologicznych. Postać Ezawa jest związana z plemieniem Edomitów, których według autorów Pisma Świętego należy uważać za jego potomków ${ }^{9}$. Tereny, które zamieszkiwali, to czerwone pustkowia i stepy o glebie czerwonej barwy. Niejednokrotnie Edomici byli wrogami Izraela i przez to stoczono z nimi niejedną bitwę (por. $2 \mathrm{Sm} 8,13$; 2 Krl 8, 20-22; 1 Krn 18, 13). Czerwony kolor, który został przypisany Ezawowi, można także porównać do barwy potrawki, za którą zrzekł się swojego pierworództwa (por. Rdz 25, 29-34).

Imię Jakuba może pochodzić od słowa aqab, które ma wieloznaczny sens. Można je przetłumaczyć jako „chwytać za piętę; pięta” lub „oszukiwać” ${ }^{10}$ W Rdz 25, 26, gdy przychodzi kolej na narodziny Jakuba, to ów wychodzi z łona matki, chwytając piętę Ezawa. Symbolika tego wydarzenia nie tylko może tłumaczyć znaczenie imienia Jakuba, ale jest już widocznym znakiem zapowiedzianej walki między braćmi. Również oszustwo ma swoje uzasadnienie $\mathrm{w}$ interpretacji znaczenia imienia Jakuba, podstępem odbiera on bowiem zarówno błogosławieństwo Izaaka, jak i pierwszeństwo Ezawa (Rdz 27, 26-30). Wściekły utratą błogosławieństwa Ezaw powie: „Nie darmo dano mu imię Jakub!...”( $\operatorname{Rdz} 27,36)$.

Oprócz tego, że słowa Jahwe zapowiedziały konflikt między braćmi już w łonie matki, ich związek jako bliźniąt również wpłynął

9 Por. D. Dziadosz, Tak byto na początku... Izrael opowiada swoje dzieje. Literacka i teologiczna analiza wiodących tradycji Ksieggi Rodzaju, Przemyś1 2011, s. 411.

10 Por. Ksiega Rodzaju, cz. 2, Rozdziaty 11, 27-36, 43, wstęp, tłum. z oryginału, komentarz oprac. J. Lemański, Częstochowa 2014, s. 622 (Nowy Komentarz Biblijny. Stary Testament, 1.2). 
na przepowiednię. Na starożytnym Bliskim Wschodzie to pierworodny syn dziedziczył podwójny majątek ${ }^{11}$. Problem mogła stanowić sytuacja bliźniąt. Pierworództwo Ezawa wynikało z tego, że pierwszy wyszedł z łona (w. 25), pomimo że miał brata bliźniaka, który trzymał się jego pięty (w. 26). Na korzyść pierwszeństwa Ezawa przemawia także fakt, że był faworyzowany przez Izaaka, m.in. za przyrządzanie mu ulubionych potrawek (w. 28).

W przeciwieństwie do Abla, który w żaden sposób nie wyrządził krzywdy starszemu bratu, Jakub wykorzystał moment słabości Ezawa przeciw niemu. Korzystając z okazji, że Ezaw był zmęczony i głodny po swojej pracy, posłużył się gorącą potrawką, by starszy bliźniak wyrzekł się swojego pierworództwa (w. 31). Ezaw wykazuje się ogromną lekkomyślnością i zrzeka się go (w. 33-34). Tym samym Jakub sprytem pokonał silnego i zwinnego myśliwego. Co ciekawe, Ezaw nie poprzysiągł żadnej pomsty z racji zrzeczenia się pierworództwa, ani bezpośrednio po tym fakcie, ani w najbliższej przyszłości. Wypomniał Jakubowi podstęp dopiero po jego kolejnym oszustwie (por. $\mathrm{Rdz} 27,26$ ). Rozważając wydarzenia zawarte we wcześniej wspomnianych wersetach, można zauważyć istotną różnicę w charakterach dwóch braci. Ezaw jest lekkomyślny i w pełni zadowalają go rzeczy przyziemne, nie myśli o tym, co się wydarzy, i nie dba o swoje dziedzictwo i majątek, które mu się należą. Z kolei Jakub jest przezorny i zabezpiecza swoją przyszłość, zdaje sobie sprawę z powagi i obfitości płynącej z faktu posiadania pierwszeństwa $^{12}$.

Bez wątpienia wydarzeniem, które definitywnie poróżniło braci, było odebranie przez Jakuba błogosławieństwa przeznaczonego dla Ezawa (Rdz 27, 18-30). Był to też najbardziej wątpliwy moralnie

11 Por. Genesis. Księga Rodzaju, tłum. i objaśn. C. Jakubiec, Warszawa 1957, s. 216.

12 Por. Ksiega Rodzaju, cz. 2, dz. cyt., s. 632-633. 
uczynek, jakiego Jakub się dopuścił. Wykorzystał nie tylko nieobecność Ezawa, ale co najgorsze - oszukał ślepego i schorowanego Izakka. Duży wpływ na jego grzech miała jego matka Rebeka, która faworyzowała drugiego syna. W podstępie to Rebeka była bardziej aktywna i zaangażowana - od przygotowania potrawki (w. 14) po ucharakteryzowanie Jakuba na owłosionego Ezawa (w. 15-16). Jakub miał jedynie ofiarować ojcu potrawkę i wiarygodnie udawać przed nim starszego brata.

Gdy cała prawda wychodzi na jaw, myśliwy wpada w szał. Oto ponownie jego brat go oszukał. Nie tylko pozbawił go wcześniej pierworództwa, ale i otrzymał błogosławieństwo ich ojca, które miało być przeznaczone Ezawowi. Zamiast błogosławieństwa myśliwy otrzymuje tzw. antybłogosławieństwo ${ }^{13}$. Przeznaczone mu będą ziemie, na których rolnictwo się nie rozwinie, będzie prowadził najemniczy tryb życia i po czasie otrzyma wolność (por. $\mathrm{Rdz} 27,39-40$ ).

Ezaw jest tak przepełniony wściekłością i nienawiścią do Jakuba, że obiecuje mu śmierć ( $\operatorname{Rdz} 27,41)$. Czeka jednak najpierw na śmierć ojca, ponieważ zdaje sobie sprawę, jak bardzo jego czyn wstrząsnąłby schorowanym i starym Izaakiem, który najprawdopodobniej nie przeżyłby takiej straty oraz straszliwej zbrodni dokonanej przez ulubionego syna. Ezaw byłby skłonny powtórzyć czyn Kaina, gdyby nie kolejna interwencja Rebeki (w. 42). Jak na ironię to los Jakuba bardziej niż los Ezawa przypominał los Kaina. Jakub był zmuszony uciec przed pełnym złości bratem, aby dalej żyć. Ucieczka do wuja Labana była nie tylko gwarancją zachowania swojego życia, ale i także częścią pokuty Jakuba za to, co uczynił bratu i ojcu. Decyzją o udaniu się do Labana w istocie ratuje dwie osoby: siebie i swojego bliźniaka Ezawa. Jakub unika śmierci oraz ratuje myśliwego od

13 Por. Ksiegga Rodzaju, cz. 2, dz. cyt., s. 691. 
dokonania bratobójstwa. Tym samym Rebeka i Jakub sprawili, że nie powtórzyła się sytuacja związana $z$ wydarzeniami opisanymi w Rdz 4.

Bracia ponownie spotykają się, kiedy mija dwadzieścia lat służby Jakuba u Labana - Jakub postanawia pojednać się z bratem, którego wcześniej tak mocno skrzywdził i pozbawił łask. Obawia się jednak, że Ezaw dalej będzie się na niego gniewał i będzie chciał dotrzymać swojej obietnicy śmierci, dlatego wysyła swoje sługi, by uprzedzili Ezawa o jego zamiarach. Gdy przekazuje sługom swój rozkaz, nazywa brata swoim panem (w. 21). Postawą pełną pokory i ofiarowanym bogactwem Jakub liczył na złagodzenie zapalczywości swojego brata bliźniaka oraz jego domniemanego gniewu. Ezaw z kolei nie odpowiada, lecz zabiera ze sobą 400 najemników. Przerażony tą sytuacją Jakub spodziewa się ataku ze strony brata.

W Rdz 33 bracia w końcu się spotykają, Jakub ze swoją rodziną i niewolnikami oraz Ezaw z 400 wojownikami. Jakub czyni pierwszy krok i siedem razy oddaje pokłon Ezawowi. Janusz Lemański podkreśla, że nie jest to zwykły gest oddania szacun$\mathrm{ku}$, ale pokłon do ziemi, jaki wykonywali Abraham dla trzech gości (por. Rdz 18, 2) oraz Lot, gdy zobaczył dwóch mężów (por. Rdz 19, 2). Był to wyraz wielkiej czci, nieraz przeznaczony dla Boga $^{14}$. Siedmiokrotny pokłon był także tradycyjnym zwyczajem oddawania szacunku przez kananejskich książąt ${ }^{15}$.

Ku wielkiemu zaskoczeniu Jakuba Ezaw podbiegł do niego, objął go i ucałował, a potem razem z bratem rozpłakał się (w. 4). Starszy $\mathrm{z}$ braci, widząc rodzinę Jakuba, z grzeczności i zapewne z zaciekawienia pyta o nią (w. 5). W dalszej części drogi do zbudowania

14 Por. J. Sulowski, Tajemnica wybrania Jakuba (Rdz 25, 19 - 37, 1), „Bobolanum"11 (2000) z. 2, s. 648.

15 Por. Księga Rodzaju. Wstęp, przektad zoryginatu, komentarz, dz. cyt., s. 635. 
dobrej relacji członkowie rodziny Jakuba po kolei oddają pokłon Ezawowi (w. 6-7). Jakub, nalegając na przyjęcie jego darów, używa dość interesującego pochlebstwa: „Bo przecież gdym ujrzał twe oblicze, było ono jakby obliczem istoty nadziemskiej, i okazałeś mi wielką życzliwość" ( $R d z$ 33, 10). Wierzono, że oblicze jest zwierciadłem duszy. Jak ponura twarz Kaina stanowiła o jego grzechu (por. $\mathrm{Rdz} 4,7$ ), tak rozpromieniona twarz Ezawa wyrażała wewnętrzną radość. Jakubowi chodzi o coś więcej. Jego dary dla bliźniaka są niczym ofiary dla Boga, a pragnie przebłagać swego brata za wyrządzone krzywdy.

Należy zadać pytanie, co sprawiło, że Ezaw tak ciepło przywitał dawno niewidzianego Jakuba. Nie można jednoznacznie odpowiedzieć na to pytanie. Nie wiadomo, czy Ezaw miał wyrzuty sumienia, gdy Jakub służył u wuja Labana, czy od niedawna był skłonny się pogodzić. Czy biorąc ze sobą 400 wojowników, chciał pierwotnie zgładzić Jakuba, czy potrzebował tylu sług, by godnie powitać dawno utraconego brata? $\mathrm{Z}$ pewnością modlitwa do Pana Boga (Rdz 32, 10-13) mogła mieć wpływ na zachowanie i postawę Ezawa.

Ezaw chciał uczynić jeszcze jedną uprzejmość względem bratazaproponował wspólną wędrówkę do Seiru (w. 12). Jednak Jakub zaczął czynić wiarygodne wymówki, by tego uniknąć. Wprawdzie pogodził się z bratem, ale nieraz był oszukiwany i znał wybuchowy charakter swojego brata. $\mathrm{Na}$ dodatek nie widział się z nim wiele lat i nie wiedział, na ile może mu ufać oraz czy nie przygotował on na niego zasadzki. Nie zgodził się na podróż, zwłaszcza gdy Ezaw chciał użyczyć mu kilku najemników (w. 15). Perspektywa wędrówki z uzbrojonymi sługami jego brata nie napawała optymizmem, więc Jakub musiał dyplomatycznie odmówić starszemu bratu. Niestety pomimo pogodzenia się Jakub ponownie oszukał brata i zamiast udać się do Seiru, wybrał Sukkot. 


\section{Józef i jego bracia}

To, co wyróżnia konflikt starszych synów Jakuba z Józefem i samego Jakuba $\mathrm{z}$ Ezawem, to nie zachowanie młodszego $\mathrm{z}$ braci, a postępowanie ojca. Niewątpliwie jedną z głównych przyczyn niezgody w rodzinie Jakuba było faworyzowanie najmłodszego syna. Powody takiego szczególnego traktowania Józefa podaje Rdz 37, 3: „Izrael miłował Józefa najbardziej ze wszystkich synów, gdyż urodził mu się on w podeszłych jego latach". Czynnikiem dodatkowym był fakt, że matką Józefa była Rachela, najbardziej umiłowana $\mathrm{z}$ matek potomstwa Jakuba. Rachela długo nie była brzemienna i urodziła syna dopiero, gdy Pan Bóg się nad nią zlitował (Rdz 30, 22). Z perspektywy Jakuba i Racheli chłopiec był $\mathrm{w}$ istocie wielkim darem od Jahwe, cudem dokonanym przez Pana Boga. Widać tu podwójną ciągłość tematyczną losu ludzi wybranych przez Boga. Rachela nie mogła stać się brzemienna podobnie jak Sara i Rebeka przed nią (por. Rdz 16, 2; 30, 22). Bóg jednak okazuje trzem kobietom litość i rodzą upragnionych synów. Podobnie Jakub zostaje ojcem w podeszłym wieku tak jak jego dziadek Abraham i ojciec Izaak.

Kolejnym powodem niechęci starszych braci była ozdobna szata, którą podarował Józefowi ojciec (w. 3). Szata była nie tylko cennym darem, ale jednocześnie wyraźnym i widocznym znakiem wielkiej miłości, jaką Jakub darzył swojego najmłodszego syna. Dar był bardzo szczególny - długa szata z rękawami (ketonet passim) pojawia się jeszcze w 2 Sm 13, 18-19, gdzie podobną nosiła Tamar, córka królewska ${ }^{16}$. Kosztowna szata sprawiła, że Józef nie mógł zajmować się pasterstwem razem z braćmi czy pracować na polu. Trudno wyobrazić sobie wykonywanie pracy bez niszczenia szaty. Miłość

16 Por. E. A. Speiser, Genesis. Introduction, Translation, and Notes, New York 1964, s. 289-290 (The Anchor Bible, 1). 
Jakuba oraz jego podarunek wywołały negatywną reakcję ze strony pozostałych synów (w. 4). Ich nienawiść była tak wielka, że przestali rozmawiać przyjaźnie ze swoim bratem. Można tu zauważyć pewien paradoks, jeśli chodzi o funkcję tak bogato zdobionej szaty. Taki ubiór zwykle miał świadczyć o wielkości i majętności jego posiadacza oraz wzbudzać podziw u każdego, kto na niego patrzył. Szata na Józefie wywołała jednak odmienny skutek i zamiast podziwu i szacunku otrzymał on zazdrość i nienawiść. Ubiór Józefa sprawił, że stał się uboższy w relacje braterskie. Wprawdzie bracia dalej korzystali z pomocy Józefa, lecz ich stosunek do niego nie różnił się od ich stosunku do służących.

Jednak tym, co naprawdę zniszczyło resztki szacunku i miłości do Józefa, była treść jego proroczych snów (por. $\operatorname{Rdz} 37,5-9$ ). W pierwszym śnie snopki braci złożyły pokłon jego snopkom (w. 6), a w drugim ciała niebieskie składały hołd Józefowi (w. 9). $\mathrm{Na}$ postawie tego, co usłyszeli synowie Jakuba, jeszcze bardziej znienawidzili swojego brata (w. 5). Wywnioskowali, że Józef chce nad nimi panować niczym król (w. 8). Dodatkowym dowodem rzekomej żądzy władzy młodszego brata miało być otrzymanie przez niego od Jakuba długiej szaty ${ }^{17}$. Dlaczego bracia byli przekonani, że sny Józefa są niczym więcej jak tylko jego fantazją i skrytymi marzeniami? Ponieważ ani razu nie przemówił w nich Bóg. Jeszcze nie zdarzyła się wcześniej sytuacja, w której Bóg milczał we śnie tego, któremu chciał przekazać swoją wolę i swe pragnienia ${ }^{18}$. Treść drugiego snu Józefa jeszcze bardziej mogła rozwścieczyć mężczyzn, ponieważ ukłon ciał niebieskich stanowiłby o niezwykle wybujałej wyobraźni Józefa oraz wielkim mniemaniu o sobie. Sny Józefa wbrew oczekiwaniom wszystkich sprawdzą się, ponieważ była w nich ukryta nie tylko wielka przyszłość Józefa, ale także

17 Por. E. A. Speiser, Genesis, dz. cyt., s. 290.

18 Por. Księga Rodzaju, cz. 2, dz. cyt., s. 69. 
wędrówka jego braci do Egiptu. Niewiara w prawdziwość snów Józefa jest potwierdzeniem nieraz przytaczanej w Piśmie Świętym prawdy, że oczekiwania i plany ludzkie nie zawsze idą w parze z planami Bożymi.

Starsi bracia, przepełnieni nienawiścią do Józefa, postawiają go zgładzić (Rdz 37, 20). Wcześniej, gdy go widzą, szyderczo mówią: „Oto nadchodzi ten, który miewa sny” (w. 19). Jedyny brat, który nie chciał śmierci Józefa, lub jedyny, który głośno się sprzeciwił, to Ruben. Jak wielka musiała być nienawiść do najmłodszego brata, skoro dziewięciu mężczyzn zgodziło się nie tylko na zamordowanie go, ale i okłamanie swojego starego ojca, że Józefa zgładziło dzikie zwierzę.

Nie jest to pierwszy raz, kiedy synowie Jakuba popełniają przestępstwo ${ }^{19}$. W Rdz 34, 24-25 Symeon i Lewi w chęci odwetu za gwałt na ich siostrze Dinie doprowadzają do zamordowania Sychema, jego ojca Chamora oraz wszystkich mężczyzn miasta. Z kolei w wersetach 27-29 pozostali bracia rabują majątki mieszkańców oraz biorą ich kobiety i trzody w niewolę.

Bracia decydują się na umieszczenie młodszego brata w opuszczonej studni (w. 20. 24). Stanisław Łach zastanawia się, jak wyglądały moralność i sumienie braci, skoro zamiast szybkiej śmierci wybrali, by Józef zginął powolną śmiercią z głodu i pragnienia ${ }^{20}$. Przy pochwyceniu Józefa zdzierają z niego szatę (w. 23), którą nie tylko chcieli przedstawić ojcu jako dowód śmierci z łap dzikiego zwierzęcia - mogli mieć satysfakcję z odebrania zdobionego ubioru. Po umieszczeniu brata w studni zasiadają do posiłku (w. 25),

19 Por. L. Boadt, Ksiega Rodzaju, w: Międzynarodowy komentarz do Pisma Świętego. Komentarz katolicki i ekumeniczny na XXI wiek, red. nauk. wyd. oryg. W. R. Farmer, współred. S. McEvenue, A. J. Levoratti, D. L. Dungan, red. nauk. wyd. pol. W. Chrostowski, współred.T. Mieszkowski, P. Pachciarek, tłum. H. Bednarek i in., Warszawa 2000, s. 303.

20 Por. Ksiega Rodzaju. Wstęp, przektad z oryginatu, komentarz, dz. cyt., s. 467. 
zupełnie nie przejmując się tym, co uczynili wcześniej. Na podstawie zachowania braci Józefa można wnioskować o ich zachwianej moralności i braku uporządkowanego sumienia. Wydaje się, że sytuacja ich przerosła, ponieważ gdy Juda proponuje sprzedaż Józefa w niewolę zamiast pozbawiania go życia, pozostali szybko aprobują tę myśl (w. 27-28). Ruben był nieobecny podczas tej rozmowy, ponieważ gdy poszedł do studni zabrać Józefa z powrotem do ojca, jego już w niej nie było (w. 29). Czyżby bracia nie chcieli wtajemniczyć Rubena w swój plan, ponieważ obawiali się jego wyraźnego sprzeciwu? Może nie chcieli wdać się w kolejną kłótnię i doprowadzić do większej eskalacji konfliktu? Niewykluczone, iż bali się możliwości, że Ruben powiedziałby Jakubowi wszystko o ich zbrodni.

Po sprzedaniu brata w niewolę bracia grzeszą po raz kolejny, pokazując ojcu szatę Józefa splamioną krwią zabitego młodego kozła. Co ciekawe, w sposób przewrotny nie mówią mu, co się stało. Pytają go, czy rozpoznaje ów ubiór. Nie podając domniemanej przyczyny śmierci Józefa, liczą na domysły ojca co do tego, jaki los spotkał jego ukochanego syna. Widząc zakrwawioną tunikę, Jakub uznaje, że Józef stał się ofiarą dzikiego zwierzęcia (w. 33). Synowie nie musieli wymyślać innej przyczyny śmierci ich brata i nie zaprzeczyli ${ }^{21}$.

Dalsze wersety opisują ogromne cierpienie ojca po rzekomej śmierci faworyzowanego syna (w. 34-35). Przepasanie bioder worem oraz opłakiwanie były niezwykle powszechną praktyką żałobną na Bliskim Wchodzie i wyrazem wielkiej straty po ukochanej osobie $^{22}$. Co najgorsze, cierpienie Jakuba było tak wielkie, że nie znalazł pocieszenia w żalu pomimo wielu prób podejmowanych

21 Por. J. Lemański, Pięcioksiag dzisiaj, Kielce 2002, s. 248-249 (Studia Biblica, 4).

22 Por. Księga Rodzaju, cz. 2, dz. cyt., s. 84. 
przez bliskich (w. 35). Zwyczajowa żałoba w Izraelu trwała siedem dni, czasami miesiąc, jednak zawsze kiedyś musiała się skończyćc ${ }^{23}$. Obserwacja cierpienia ojca musiała wpłynąć na postawę jego pozostałych synów na tyle, że w ramach nadanej sobie pokuty dbali i troszczyli się o ich kolejnego najmłodszego brata Beniamina.

Minie wiele lat, zanim Józef ponownie spotka się ze swoimi braćmi. Podczas gdy tamci zajmowali się codziennymi obowiązkami, Józef trafił na służbę do Potifara w Egipcie ( $\operatorname{Rdz} 37,36)$, był również w więzieniu wskutek fałszywych oskarżeń żony tegoż urzędnika ( $R d z$ 37, 17-19). Dzięki swoim niezwykłym snom stał się zarządcą Egiptu i drugą osobą w państwie zaraz po faraonie; zaakceptował także zmianę swego hebrajskiego imienia na egipskie Safnat Paneach (Rdz 41, 42-45).

Bracia Józefa udali się do Egiptu, by zakupić zboże ( $\operatorname{Rdz} 42,3)$. Tylko Beniamin został z ojcem, jako że ten nie chciał, by stała mu się krzywda podczas podróży z braćmi (w. 3). Z pewnością mając na względzie, jak według niego skończył swe życie Józef, nie chciał stracić kolejnego ukochanego syna.

Jako że Józef był odpowiedzialny za sprzedaż zboża, potomkowie Jakuba udali się do niego i oddali mu pokłon. I tak po tylu latach spełnił się pierwszy proroczy sen Józefa, tak bardzo niegdyś wyszydzony przez jego braci (por. Rdz 37, 6-7). Józef zwrócił uwagę na ten fakt dopiero, gdy do niego przemówili (w. 9). Rozwścieczony i żądny zemsty, oskarża ich o szpiegostwo i kłamstwo, jako że gdy spytał ich o najmłodszego z braci, odrzekli, że został z ojcem (w. 13). Józef, nie wiedząc o istnieniu Beniamina, jeszcze bardziej się denerwuje. Pomyślał, że mężczyźni go okłamują, skoro według jego toku myślenia miał być tym młodszym bratem. Daje im jednak szansę na ułaskawienie, ale jedynie wtedy, gdy przyprowadzą młodszego brata przed jego oblicze. Dochodzi do niezwykłej rozmowy między

23 Por. Ksiegga Rodzaju, cz. 2, dz. cyt., s. 85. 
braćmi. Użalają się nad swoim losem i zdają się żałować tego, co uczynili Józefowi, gdy go pojmali. Ruben jest tak zły na braci, że wypomina im brak usłuchania go, gdy mówił im o pozostawieniu Józefa przy życiu²4.

Bracia zgadzają się przyprowadzić Beniamina przed oblicze wielkiego Safnat Paneacha pomimo niechęci Jakuba (por. Rdz 43, 11-14). Józef bardzo wzruszył się na widok młodszego brata, ponieważ tak samo jak on był synem Racheli, umiłowanej żony Jakuba (w. 29-30). Poza tym Beniamin jako jedyny z braci był niewinny i w żaden sposób nie brał udziału w sprzedaży brata w niewolę. Józef podczas uczty $(\operatorname{Rdz} 44,1)$ chciał sprawdzić uczciwość braci- nie tylko mówili prawdę, ale i spełnili dokładnie jego polecenia dotyczące przyprowadzenia przed jego oblicze Beniamina. Zaczął powoli wierzyć w przemianę braci w moralnie dojrzałych ludzi. Kazał słudze podrzucić srebrny puchar Beniaminowi, by rzucić na niego podejrzenie bycia złodziejem. Nie chciał zaszkodzić bratu, ale w ostateczny sposób przekonać się o uczciwości pozostałych. Gdy zażądał, by Beniamin został na zawsze jego sługą i pozostał w Egipcie (w. 10), przerażony oraz skruszony Juda znalazł w sobie siłę i wyjaśnił mu powody, dlaczego nie może tego uczynić (w. 18-34). Swoistą spowiedź w imieniu braci wygłosił właśnie Juda, jako że obiecał swojemu ojcu szczęśliwy powrót Beniamina do domu ${ }^{25}$. Podał nie tylko powody, dlaczego Beniamin musi wrócić do domu, ale też opowiedział, co się stanie z ich ojcem, jeśli dowie się, co się stało z jego ukochanym synem. Juda czułby się tak pohańbiony, widząc to wszystko, że wolałby spędzić resztę życia w niewoli w Egipcie niż patrzeć na cierpienie swojego ojca.

24 Por. B. Poniży, Schemat losów Dawida (Rdz 37-50) w tekstach biblijnych, w: Scriptura Sacra Posnaniensis, opuscula M. Wolniewicz octogenario dedicata, red. F. Lenort, Poznań 2002, s. 79 (Opuscula Dedicata, 3).

25 Por. Genesis. Ksiegra Rodzaju, dz. cyt., s. 309. 
Monolog Judy zrobił tak wielkie wrażenie na Józefie, że nie mógł już dalej ukryć łez. Wyjawił mężczyznom swoją prawdziwą tożsamość i pogodził się z nimi.

Miał im do przekazania bardzo ważną nowinę. Prawdę, którą być może znał od dawna, ale przez mowę Judy upewnił się co do jej słuszności: „Ale teraz nie smućcie się i nie wyrzucajcie sobie, żeście mnie sprzedali. Bo dla waszego ocalenia od śmierci Bóg wysłał mnie tu przed wami. [...] Bóg mnie wysłał przed wami, aby wam zapewnić potomstwo na ziemi i abyście przeżyli dzięki wielkiemu wybawieniu. Zatem nie wyście mnie tu posłali, lecz Bóg, który też uczynił mnie doradcą faraona, panem całego jego domu i władcą całego Egiptu” ( $\operatorname{Rdz} 45,5-8)$.

Choć bracia popełnili wielki grzech względem Józefa, Jakuba i Pana Boga, to nie przeszkodziło to w planach Bożych. Bóg sprawił, że zło, które zostało wyrządzone przez potomków Izraela, mogło stać się przyczyną dobrobytu dla Jego ludu. Trzeba było wielu lat, by bracia mogli ponownie się spotkać i wzajemnie przebaczyć sobie winy.

\section{Podsumowanie}

Księga Rodzaju ukazuje skomplikowane relacje braterskie. Na przykładzie Kaina i Abla, Ezawa i Jakuba oraz Józefa i jego braci można zauważyć podobny schemat - starszy brat okazuje wrogość młodszemu. W wyżej wymienionych parach braci za każdym razem dochodziło do próby pozbawienia życia. Tylko Kain dokonuje mordu, natomiast działania Ezawa oraz braci Józefa zostają udaremnione. Jakub i Józef muszą rozdzielić się ze swoimi braćmi, by ponownie się z nimi po latach spotkać i pojednać. Tylko Jakub czyni podwójną krzywdę swojemu bratu. Podstępem wykrada zarówno pierworództwo, jak i błogosławieństwo Izaaka. 
$\mathrm{Na}$ dalszą eskalację konfliktu miały wpływ osoby trzecie. Kain zazdrości Ablowi stosunków z Panem Bogiem, odczuwa również brak zainteresowania ze strony Jahwe ( $\operatorname{Rdz} 4,5)$. Jakubowi w kradzieży błogosławieństwa pomaga matka, która deklaruje, że bierze jego grzech na swoją osobę $(\operatorname{Rdz} 27,13)$. Ostrzega syna przed gniewem bliźniaka i zaleca mu ucieczkę do Labana (Rdz 27, 43-44). Faworyzowanie Józefa przez Jakuba i okazywanie przez niego tegoż faktu powoduje coraz większą nienawiść jego braci. Również osoby trzecie starały się jednak zapobiec dokonaniu mordu. Będą to kolejno: Bóg, Rachela oraz Ruben ( $\operatorname{Rdz} 4$, 7; 27, 42-45; 37, 22).

Odmiennie układają się losy braci, którzy zaognili konflikt. Kain zostaje przeklęty przez Boga. W wyniku przekleństwa nie będzie mógł uprawiać roli, będzie prowadził koczowniczy tryb życia oraz żył z piętnem mordercy do końca swoich dni ( $\operatorname{Rdz} 4,11-16)$. Ezaw w wyniku swojej lekkomyślności doprowadza do utraty swego pierworództwa ( $\mathrm{Rdz} 25$, 29-34). Przez podstęp Jakuba traci również błogosławieństwo ojca i zostają mu przeznaczone pustkowia Edomu ( $\operatorname{Rdz} 27,39)$. Bracia Józefa w ramach nałożonej na siebie pokuty będą opiekowali się Beniaminem oraz przeżywać cierpienie Jakuba ( $\mathrm{Rdz} 37,35)$. Wisieć nad nimi będzie groźba głodu i śmierci.

Konflikt braterski w Księdze Rodzaju można także tłumaczyć etiologicznie. Kaina i Ezawa uważa się za protoplastów Kainitów oraz Edomitów ( $R d z 4$, 17-21; 36, 1-43), którzy wielokrotnie mieli konflikty zbrojne z Izraelem. Również plemiona Izraela nie zawsze żyły ze sobą w zgodzie.

W relacjach braterskich przedstawionych w Księdze Rodzaju można ujrzeć piękny obraz miłości i troski Pana Boga. Jahwe nie tylko wyjawia Kainowi przyczynę jego złości, mówi mu także, co powinien zmienić w swoim postępowaniu, by uniknąć grzechu $(\operatorname{Rdz} 4,7)$. Również Bóg towarzyszy w wędrówce Józefa, jak wcześniej to czynił z Jakubem ( $\operatorname{Rdz} 32,2$. 25-30). Jahwe zsyła także 
Józefowi prorocze sny, które ratują zarówno mieszkańców Egiptu, jak i rodzinę Jakuba od głodu i śmierci ( $R d z$ 47, 23-24).

\section{Wybrana bibliografia}

1. Boadt L., Księga Rodzaju, w: Międzynarodowy komentarz do Pisma Świętego. Komentarz katolicki i ekumeniczny na XXI wiek, red. nauk. wyd. oryg. W. R. Farmer, współred. S. McEvenue, A. J. Levoratti, D. L. Dungan, red. nauk. wyd. pol. W. Chrostowski, współred.T. Mieszkowski, P. Pachciarek, tłum. H. Bednarek i in., Warszawa 2000, s. 264-310.

2. Dziadosz D., Tak byto na poczatku... Izrael opowiada swoje dzieje. Literacka i teologiczna analiza wiodacych tradycji Ksiegi Rodzaju, Przemyśl 2011.

3. Genesis. Księga Rodzaju, tłum. i objaśn. C. Jakubiec, Warszawa 1957.

4. Księga Rodzaju, cz. 1, Rozdziaty 1-11, wstęp, tłum. z oryginału, komentarz oprac. J. Lemański, Częstochowa 2013 (Nowy Komentarz Biblijny. Stary Testament, 1.1).

5. Księga Rodzaju, cz. 2, Rozdziaty 11, 27-36, 43, wstęp, tłum. z oryginału, komentarz oprac. J. Lemański, Częstochowa 2014 (Nowy Komentarz Biblijny. Stary Testament, 1.2).

6. Księga Rodzaju. Wstęp, przektad z oryginatu, komentarz, oprac. S. Each, Poznań 1962 (Pismo Święte Starego Testamentu, 1.1).

7. Lemański J., Pięcioksiąg dzisiaj, Kielce 2002 (Studia Biblica, 4).

8. Majewski M., Biblijna historia zbawienia, wyd. 2 popr., Kraków 2017, https://www.academia.edu/10942402/BIBLIJNA_HISTORIA_ZBAWIENIA (20.08.2019).

9. Peter M., Prebistoria biblijna, Poznań 1994 (Biblioteka Pomocy Naukowych - Papieski Wydział Teologiczny w Poznaniu, 10). 
10. Pikor W., Zbawienie - zmaganie o Boże oblicze na twarzy Kaina (Rdz 4, 1-16), „Verbum Vitae”1 (2002), s. 29-39.

11. Poniży B., Schemat losów Dawida (Rdz 37-50) w tekstach biblijnych, w: Scriptura Sacra Posnaniensis, opuscula M. Wolniewicz octogenario dedicata, red. F. Lenort, Poznań 2002, s. 65-90 (Opuscula Dedicata, 3).

12. Schedl C., Starożytny Wschód i prehistoria biblijna, tłum. S. Stańczyk, Tuchów 1995 (Historia Starego Testamentu, 1).

13. Speiser E. A., Genesis. Introduction, Translation, and Notes, New York 1964 (The Anchor Bible, 1).

14. Sulowski J., Tajemnica wybrania Jakuba (Rdz 25, 19 - 37, 1), „Bobolanum” 11 (2000) z. 2, s. 459-473. 
A/4 Uniwersytet Papieski

Tfon Jana Pawla II 